\title{
Penggunaan Permainan Bahasa untuk Meningkatkan Aktivitas Siswa Kelas IV A SD Negeri 01 Metro Pusat
}

\author{
Arifin Ahmad \\ Program Studi Pendidikan Guru Sekolah Dasar, Universitas Pasundan \\ arifinahmad@unpas.ac.id
}

\begin{tabular}{|c|c|}
\hline Kata Kunci: & Abstrak \\
\hline $\begin{array}{l}\text { permainan } \\
\text { bahasa, } \\
\text { aktivitas, } \\
\text { siswa }\end{array}$ & $\begin{array}{l}\text { Aktivitas siswa di saat pembelajaran berlangsung dapat menjadi salah satu indikator } \\
\text { keberhasilan seorang guru dalam mengajar. Semakin meningkat aktivitasnya semakin } \\
\text { baik pembelajaranya begitu juga sebaliknya. Peningkatan aktivitas siswa tersebut bisa } \\
\text { dilakukan dengan menerapkan model pembelajaran yang bervariatif. Namun pada } \\
\text { kenyataanya pembelajaran di kelas IVA SD Negeri 01 Metro Pusat masih belum } \\
\text { menggunakan model pembelajaran yang bervariatif sehingga membuat siswa kurang } \\
\text { tertarik dan kurang memperhatikan. Aktivitas siswapun dalam pembelajarannya } \\
\text { cenderung pasif. Penelitian ini bertujuan untuk meningkatkan aktivitas siswa melalui } \\
\text { penggunaan permainan bahasa di kelas IVA SD Negeri 01 Metro Pusat. Metode } \\
\text { penelitian yang digunakan dalam penelitian ini yaitu metode kualitatif melalui } \\
\text { penelitian tindakan kelas (classroom action research). Teknik analisis data yang } \\
\text { digunakan adalah analisis kualitatif untuk mengungkapkan semua aktivitas siswa serta } \\
\text { perubahannya selama proses pembelajaran dan dituangkan dalam bentuk persentase. } \\
\text { Berdasarkan hasil analisis data diperoleh aktivitas siswa dari siklus I (70,69\%) ke } \\
\text { siklus II (80\%), mengalami peningkatan sebesar 9,31\% dan dari siklus II (80\%) ke } \\
\text { siklus III menjadi (90,70\%) sehingga mengalami peningkatan sebesar } 13,72 \% \text {. }\end{array}$ \\
\hline Keywords: & Abstract \\
\hline $\begin{array}{l}\text { language } \\
\text { games, } \\
\text { student, } \\
\text { activities }\end{array}$ & $\begin{array}{l}\text { Student activities while learning is taking place can be one of indicator of successful } \\
\text { teachers. The more activites increase the better the learning and vice versa. The } \\
\text { increase in student activities can be done by applying various learning model. On the } \\
\text { contrary learning in class IVA SD Negeri } 01 \text { Metro Pusat still does not use a variety of } \\
\text { model, and this makes students becoming less interested and less attention. Student } \\
\text { activities in learning tend to be passive. This study aims is to increase the activity of } \\
\text { students through the use of language games in class IVA SD Negeri } 01 \text { Metro Pusat. } \\
\text { The research method used in this study is qualitative methods through classroom } \\
\text { action research. The data analysis technique used is qualitative analysis in order to } \\
\text { reveal all student activities and their changes during the learning process and set out in } \\
\text { percentage form. Based on the results of data analysis, the students' activities were } \\
\text { obtained from the first cycle ( } 70.69 \%) \text { to the second cycle ( } 80 \%) \text {, competency } \\
\text { improvement was } 9.31 \% \text { and from the second cycle ( } 80 \%) \text { to the third cycle became } \\
(90.70 \%) \text { so the increase is } 13.72 \% \text {. }\end{array}$ \\
\hline
\end{tabular}

\section{A. Pendahuluan}

Memasuki era teknologi yang berkembang pesat seperti sekarang ini menuntut hadirnya peran guru dalam mengimplementasikan pembelajaran yang tidak hanya kreatif dan inovatif saja tetapi juga harus dipastikan bahwa pembelajaran tersebut mampu mengaktifkan siswa dan pada akhirnya terasa menyenangkan. Oleh karena itu guru harus mampu menghadirkan model pembelajaran yang bervariatif. Karena jika guru minim menggunakan model pembelajaran maka membuat pembelajaranya monoton, aktivitas kegiatan siswa menjadi pasif sehingga pemeblejaranpun menjadi tidak berhasil. Hal tesebut sejalan dengan pernyataan Mulyasa (2002) bahwa pembelajaran dikatakan berhasil dan berkualitas apabila seluruhnya atau setidak- 
tidaknya sebagian besar siswa terlibat secara aktif, baik fisik, mental maupun sosial dalam proses pembelajaran. Kemudian Sudjana (2004) juga mengatakan bahwa ciri pengajaran yang berhasil salah satu diantaranya dilihat dari kadar kegiatan belajar siswa. Makin tinggi kegiatan belajar siswa, makin tinggi peluang berhasilnya pengajaran.

Aktivitas siswa dalam pembelajaran menjadi sangat penting karena keaktifan siswa dalam pembelajaran dapat mengembangan cara berpikirnya, emosinya, dan sosialnya. Usaha yang dapat dilakukan guru untuk mampu mengaktifkan siswa di dalam pembelajaran diantaranya adalah menggunakan model pembelajaran yang menarik serta menyenangkan, salah satu model pembelajaran yang menarik dan menyenangkan serta dapat membuat siswa aktif adalah model permainan. Model permainan tidak hanya memeberikan rasa senang tetapi juga memberikan banyak manfaat, seperti pernyataan Solehuddin (dalam Hamdani, 2011) bahwa permainan dalam pembelajaran mempunyai banyak manfaat antara lain: a) pengalaman belajar dirasakan dan dipersepsikan secara alami oleh siswa yang bersangkutan sehingga menjadi bermakna baginya; b) siswa memiliki kesempatan untuk membangun dunianya berinteraksi dengan orang lain dalam lingkungan sosial, mengekspresikan dan mengontrol emosinya, serta mengembangkan kecakapan simboliknya; c) siswa memperoleh kesempatan untuk mempraktikkan keterampilan-keterampilan yang baru diperolehnya dan juga fungsi kecakapan sosialnya untuk menerima peran sosial yang baru, mencoba tugas baru yang menantang, serta menyelesaikan masalah-masalah baru yang tidak dapat diselesaikan dengan cara lain. Selanjutnya Piaget dan Vigotsky (dalam Charner, dkk. 2006) mengemukakan bahwa bermain merupakan salah satu komponen terpenting dalam kesuksesan siswa di sekolah. Melalui bermain siswa belajar berkomunikasi, bernegosiasi, mengelola peraturan, memperoleh pengetahuan, dan memperluas keahlian berpikir mereka. Permainan dalam pembelajaran ada banyak macamnya, adapun permainan yang digunakan dalam penelitian ini adalah permainan bahasa. Soeparno (dalam Djuanda, 2006) menjelaskan bahwa pada hakikatnya permainan merupakan suatu aktivitas untuk memperoleh suatu keterampilan tertentu dengan cara yang menggembirakan, jika keterampilan yang diperoleh dalam permainan itu berupa keterampilan bahasa tertentu, permainan itu dinamakan permainan bahasa.

Berdasarkan hal di atas peneliti melihat bahwa penggunaan model yang bervariatif di dalam pembelajaran menjadi tuntutan bagi guru untuk mampu menghadirkanya supaya siswa aktif dan menyenangkan serta mampu mengembangkan segala potensi di dalam dirinya. Namun pada kenyataan di lapangan berdasarkan hasil observasi peneliti di kelas IVA SD Negeri 01 Metro Pusat, guru masih kurang menggunakan model pembelajaran yang bervariatif. Guru di kelas IVA SD Negeri 01 Metro Pusat masih menerapkan model yang kurang mengaktifkan siswa dalam pembelajaranya seperti guru langsung mengajak siswa mempelajari materi yang akan dilaksanakan tanpa menggunakan apersepsi. Pada inti pembelajaran guru yang dominan menyampaikan materi sedangkan siswa pasif menerima. Pada kegiatan akhir guru langsung menutup pembelajaran tanpa merefleksi materi yang telah diberikan sebelumnya. Karena pembelajaran yang dilakukan guru seperti itu maka membuat siswa kurang aktif dan kurang tertarik pada sehingga siswa kurang memperhatikan pembelajaran.

Untuk solusi permasalhan di atas, maka diperlukan model pembelajaran yang mampu mewujudkan situasi pembelajaran yang aktif dan menyenangkan. Salah satu model pembelajaran tersebut adalah model permainan bahasa, karena dengan model permainan bahasa siswa diajak untuk belajar aktif dalam suasana yang menarik dan menyenangkan. Hal tersebut sesuai dengan pendapat Suyatno (2005) bahwa dalam pembelajaran itu harus menarik dan menyenangkan, karena pembelajaran yang menarik berarti mempunyai unsur yang menggelitik bagi siswa untuk terus diikuti, siswa mempunyai motivasi untuk terus mengikuti pembelajaran. 
Adapun tujuan penelitian ini adalah: Meningkatkan aktivitas belajar siswa melalui penggunaan permainan bahasa pada pembelajaran di kelas IVA SD Negeri 01 Metro Pusat.

\section{B. Metodologi}

Metodologi dalam penelitian ini menggunakan metode kualitatif melalui penelitian tindakan kelas (classroom action research). Penelitian tindakan kelas adalah penelitian yang dilakukan oleh guru di dalam kelasnya sendiri melalui refleksi diri, dengan tujuan untuk memperbaiki kinerjanya sebagai guru (Wardhani, 2007). Siklus tindakan dalam penelitian ini digambarkan sebagai berikut.

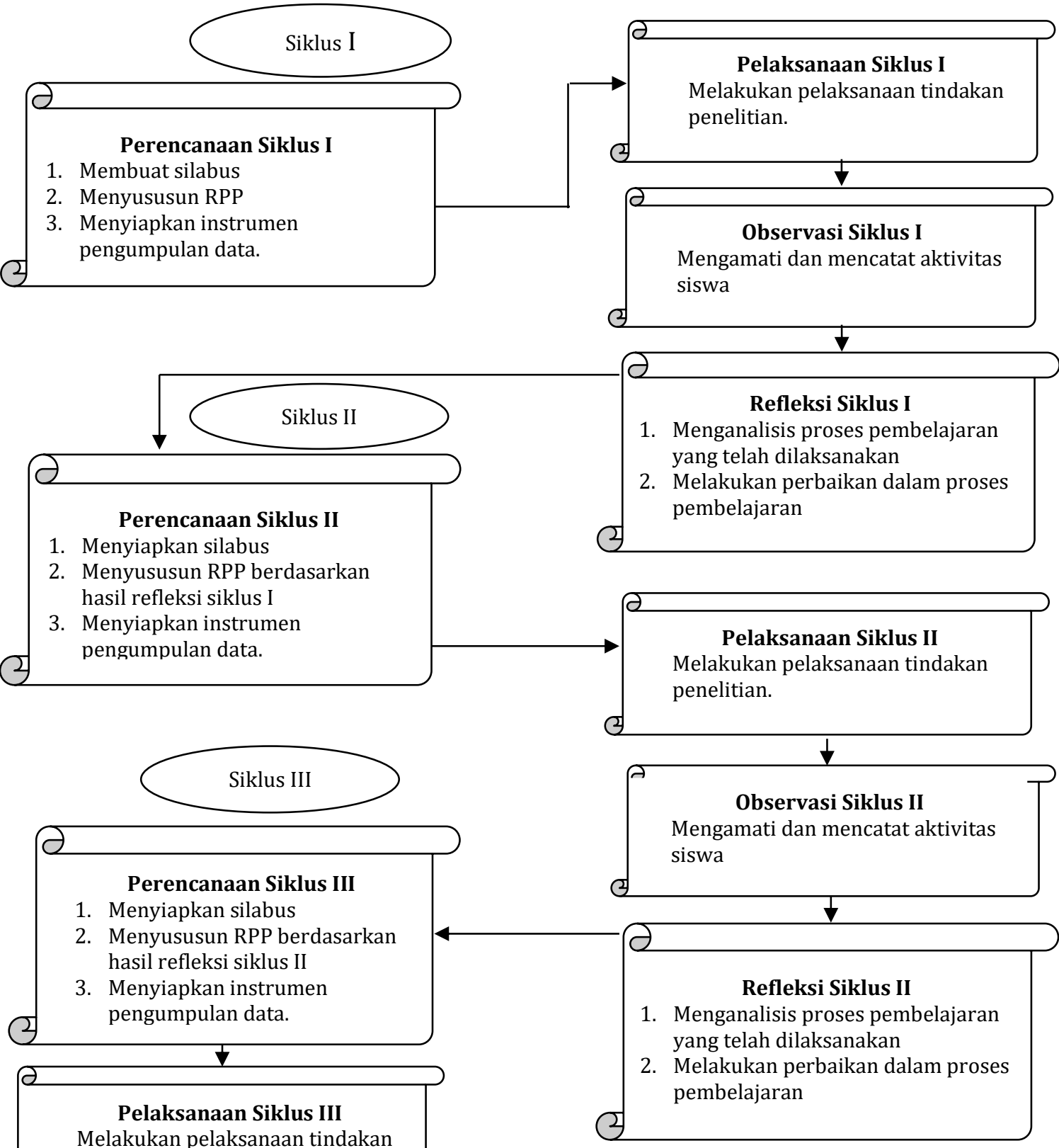




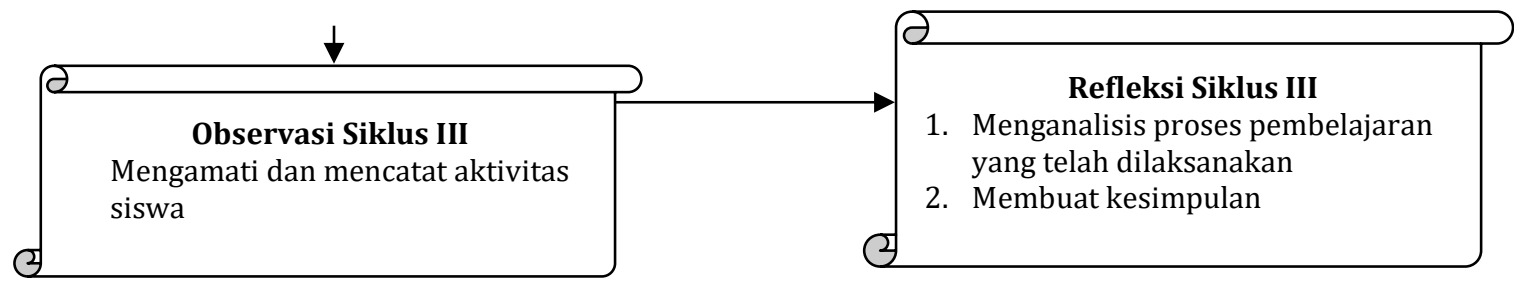

Penelitian ini dilaksanakan di SD Negeri 01 Metro Pusat, Kota Metro Provinsi Lampung. Subjek penelitian adalah siswa kelas IVA SD Negeri 01 Metro Pusat dengan jumlah 43 siswa, siswa perempuan 21 orang dan siswa laki-laki 22 orang. Pengumpulan data pada penelitian ini menggunakan teknik nontes yang digunakan untuk mengetahui respon aktivitas siswa terhadap pembelajaran melalui permainan bahasa. Teknik pengumpulan data yang digunakan dalam penelitian ini adalah dengan menggunakan alat pengumpul data, yaitu catatan hasil amatan (observasi) aktivitas siswa. Adapun aktivitas siswa yang diamati adalah perhatian dan partisipasi siswa dalam pembelajaran. Untuk indikator perhatian siswa antara lain; memperhatikan apa yang disampaikan oleh guru, mengikuti petunjuk guru, dan berinteraksi dengan teman. Untuk indikator partisipasi siswa antara lain; berdiskusi, bekerja sama, dan menghargai pendapat teman. Teknik analisis data yang digunakan adalah analisis kualitatif untuk mengungkapkan semua aktivitas siswa serta perubahannya selama proses pembelajaran dari siklus I, II, dan siklus III dengan menggunakan bentuk persentase. Persentase yang ditargetkan dalam penelitian ini adalah $\geq 85 \%$ dari jumlah siswa dalam satu kelas. Adapun untuk rumus penilaian aktivitas siswa adalah sebagai berikut.

$$
N P=\frac{R}{S M} x 100
$$

Keterangan:

$\mathrm{NP}=$ Nilai persen yang dicari atau diharapkan

$\mathrm{R}=$ Skor mentah yang diperloleh dari lembar instrumen observasi

$\mathrm{SM}=$ Skor maksimum nilai pada lembar instrumen observasi

$100=$ Bilangan tetap

\section{Hasil dan Pembahasan}

Penelitian ini dilakukan dalam tiga siklus, setiap siklus terdapat dua pertemuan. Berdasarkan hasil observasi diperoleh data hasil aktivitas siswa setiap siklus sebagai berikut.

a. Data aktivitas siswa dalam pembelajaran siklus I

Aktivitas siswa pada siklus I dituangkan dalam tabel berikut.

Tabel 1. Hasil aktivitas siswa dalam pembelajaran siklus I

\begin{tabular}{|c|c|c|c|c|c|}
\hline Pertemuan ke & Skor maksimal & Skor perolehan & Persentase & Rata-rata & Target \\
\hline 1 & 430 & 294 & $68,37 \%$ & \multirow{2}{*}{$70,69 \%$} & \multirow{2}{*}{$\geq 85 \%$} \\
\hline 2 & 430 & 314 & $73,02 \%$ & & \\
\hline
\end{tabular}

Berdasarkan tabel 1, dapat dilihat bahwa aktivitas siswa pada saat pembelajaran menggunakan permainan bahasa siklus I pertemuan 1 menunjukkan persentase aktivitas siswa sebesar $68,37 \%$, dari indikator yang diukur sebagian besar siswa memperhatikan apa yang disampaikan oleh guru, namun masih ada sebagian siswa kurang memperhatikan petunjuk dari guru sehingga pelaksanaan pembelajaran kurang efektif dan kondusif. Pada kegiatan partisipasi 
siswa dalam kelompok, hanya sebagian siswa yang berdiskusi, bekerja sama, dan menghargai pendapat teman dalam menyampaikan pendapat. Pada pertemuan 2 meningkat menjadi 73,02\%, siswa mulai aktif dalam proses pembelajaran, dan sebagian siswa sudah dapat berinteraksi dengan teman secara baik. Berdasarkan persentase aktivitas siswa siklus I pertemuan 1 dan 2, diperoleh persentase rata-rata aktivitas siswa sebesar 70,69\%, hal tersebut belum mencapai indikator keberhasilan yang ditargetkan yaitu persentase aktivitas siswa $\geq 85 \%$. Untuk refleksi dari siklus I ke siklus II adalah guru lebih memberikan bimbingan kepada siswa yang kurang memperhatikan petunjuk, sehingga pelaksanaan pembelajaran menjadi lebih efektif dan kondusif lagi pada siklus II. Kemudian guru juga harus menegaskan kembali bahwa tugas kelompok yang dikerjakan bukanlah mengerjakan sendiri-sendiri tetapi bekerja sama atau kerja tim sehingga pada siklus II siswa dapat meningkatkan kegiatan diskusi kelompoknya, meningkatkan kerja sama kelompoknya, dan lebih menghargai pendapat teman dalam menyampaikan pendapat.

b. Data aktivitas siswa dalam pembelajaran siklus II

Aktivitas siswa pada siklus II dituangkan dalam tabel berikut.

Tabel 2. Hasil aktivitas siswa dalam pembelajaran siklus II.

\begin{tabular}{|c|c|c|c|c|c|}
\hline Pertemuan ke & Skor maksimal & Skor perolehan & Persentase & Rata-rata & Target \\
\cline { 1 - 4 } & 430 & 334 & $77,67 \%$ & $80 \%$ & $\geq 85 \%$ \\
\cline { 1 - 4 } & 430 & 354 & $82,33 \%$ & & \\
\hline
\end{tabular}

Berdasarkan tabel 2, dapat dilihat bahwa aktivitas siswa pada saat pembelajaran menggunakan permainan bahasa siklus II pertemuan ke 1 menunjukkan persentase aktivitas siswa sebesar 77,67\%, dari indikator yang diukur sudah ada siswa yang memperoleh skor maksimal, yaitu memperhatikan apa yang disampaikan oleh guru, berinteraksi dengan teman secara baik, dan memperhatikan petunjuk dari guru sehingga pelaksanaan pembelajaran efektif dan kondusif. Pada kegiatan partisipasi siswa dalam kelompok, sedikit siswa yang berdiskusi, bekerja sama dengan baik dan menghargai pendapat teman. Sebagian besar siswa berdiskusi, bekerja sama dengan baik tetapi masih kurang menghargai pendapat teman dalam menyampaikan pendapat. Pada pertemuan 2 meningkat menjadi 82,33\%, siswa semakin aktif dalam proses pembelajaran, mulai dari memperhatikan apa yang disampaikan guru, mengikuti penjelasan dan petunjuk guru, serta sebagian siswa sudah dapat berinteraksi dengan teman secara baik. Berdasarkan persentase aktivitas siswa siklus II pertemuan 1 dan 2, diperoleh persentase rata-rata aktivitas siswa sebesar $80 \%$, hal tersebut belum mencapai indikator keberhasilan yang ditargetkan yaitu persentase aktivitas siswa $\geq 85 \%$. Untuk refleksi dari siklus II ke siklus III adalah perlu adanya pengarahan yang lebih intensif bagi kelompok yang masih terlihat bekerjanya secara individu. Kemudian Guru menegaskan kembali bahwa tugas kelompok yang dikerjakan bukanlah mengerjakan sendiri-sendiri tetapi bekerja sama atau kerja tim, sehingga setiap anggota kelompok harus berperan aktif dalam kelompoknya.

c. Data aktivitas siswa dalam pembelajaran siklus III

Aktivitas siswa pada siklus III dituangkan dalam tabel berikut.

Tabel 3. Hasil aktivitas siswa dalam pembelajaran siklus II.

\begin{tabular}{|c|c|c|c|c|c|}
\hline Pertemuan ke & Skor maksimal & Skor perolehan & Persentase & Rata-rata & Target \\
\hline 1 & 430 & 374 & $86,98 \%$ & $89,31 \%$ & $\geq 85 \%$ \\
\cline { 1 - 4 } 2 & 430 & 394 & $91,63 \%$ & & \\
\hline
\end{tabular}


Berdasarkan tabel 3, dapat dilihat bahwa aktivitas siswa pada saat pembelajaran menggunakan permainan bahasa siklus III pertemuan 1 menunjukkan persentase aktivitas siswa sebesar $86,98 \%$, dari indikator yang diukur sebagian besar siswa memperoleh skor maksimal pada aspek perhatian siswa, yaitu memperhatikan apa yang disampaikan oleh guru, berinteraksi dengan teman secara baik, dan memperhatikan petunjuk dari guru sehingga pelaksanaan pembelajaran efektif, kondusif, dan menyenangkan. Pada kegiatan partisipasi siswa dalam kelompok, sebagian besar siswa sudah dapat berdiskusi, bekerja sama dengan baik dan menghargai pendapat teman. Pada pertemuan 2 meningkat menjadi 91,63\%, siswa semakin aktif dalam proses pembelajaran, hampir seluruh dari jumlah siswa telah memperhatikan apa yang disampaikan guru, mengikuti penjelasan dan petunjuk guru, serta sebagian siswa sudah dapat berinteraksi dengan teman secara baik. Kemudian peningkatan juga terjadi pada aspek partisipasi dalam kelompok. Berdasarkan persentase aktivitas siswa siklus III pertemuan 1 dan 2 , diperoleh persentase rata-rata aktivitas siswa sebesar $89,31 \%$, hal tersebut sudah mencapai indikator keberhasilan yang ditargetkan yaitu persentase aktivitas siswa $\geq 85 \%$. Berdasarkan data yang telah diperoleh pada kegiatan siklus III maka berikut refleksi untuk pembelajaran siklus III yang telah dilaksanakana. Dari hasil observasi terlihat bahwa penggunaan model permainan bahasa dalam kegiatan pembelajaran telah berhasil diterapkan dengan baik. Hal ini dapat dilihat dari meningkatnya aktivitas siswa pada saat pembelajaran berlangsung. Jika dibandingkan dengan siklus I dan II maka pada siklus III dari hasil observasi kegiatan siswa terdapat kemajuan yang lebih baik lagi. Selain itu meskipun dalam kegiatan pembelajaran terdapat hambatan yang dihadapi oleh siswa maupun guru, namun dapat diatasi dengan baik dan akhirnya target juga mencapai rata-rata $89,31 \%$. Dengan mempertimbangkan hal tersebut maka peneliti memutuskan untuk tidak melanjutkan penelitian karena hasil yang diperoleh telah mencapai target yang ditetapkan.

Berdasarkan hasil pembahasan aktivitas siswa di atas, diperoleh data sebagai berikut. Aktivitas siswa dalam proses pembelajaran menggunakan permainan bahasa dapat berjalan dengan baik dan terus mengalami peningkatan dari siklus I sampai siklus III dan sampai pada target yang ditentukan. Berdasarkan pengamatan dapat dilihat rekapitulasi peningkatan aktivitas siswa dalam proses pembelajaran menggunakan model permainan bahasa sebagai berikut.

Tabel 4. Rekapitulasi peningkatan persentase aktivitas siswa dalam proses pembelajaran.

\begin{tabular}{|c|c|c|c|c|c|c|c|c|c|}
\hline \multirow[b]{3}{*}{ No } & \multicolumn{9}{|c|}{ SIKLUS } \\
\hline & \multicolumn{3}{|c|}{ I } & \multicolumn{3}{|c|}{ II } & \multicolumn{3}{|c|}{ III } \\
\hline & $\begin{array}{l}\text { Pert. } 1 \\
(\%)\end{array}$ & $\begin{array}{l}\text { Pert. } 2 \\
\text { (\%) }\end{array}$ & $\begin{array}{c}\text { Peningkatan } \\
\text { (\%) }\end{array}$ & $\begin{array}{l}\text { Pert. } 1 \\
\text { (\%) }\end{array}$ & $\begin{array}{l}\text { Pert. } 2 \\
\text { (\%) }\end{array}$ & $\begin{array}{c}\text { Peningkatan } \\
\text { (\%) }\end{array}$ & $\begin{array}{c}\text { Pert. } 1 \\
(\%)\end{array}$ & $\begin{array}{c}\text { Pert. } 2 \\
(\%)\end{array}$ & $\begin{array}{c}\text { Peningkatan } \\
\text { (\%) }\end{array}$ \\
\hline 1 & 68,37 & 73,02 & 4,65 & 77,67 & 82,33 & 4,66 & 86,98 & 91,63 & 4,65 \\
\hline $\begin{array}{l}\text { Rata- } \\
\text { rata }\end{array}$ & \multicolumn{3}{|c|}{$70,69 \%$} & \multicolumn{3}{|c|}{$80 \%$} & \multicolumn{3}{|c|}{$93,72 \%$} \\
\hline
\end{tabular}

Berdasarkan data tabel 4, yang diperoleh dari hasil observasi aktivitas siswa dalam proses pembelajaran siklus I, II, dan III, maka dapat diuraikan sebagai berikut. Hasil persentase ratarata aktivitas siswa pada siklus I adalah 70,69\% di siklus II meningkat menjadi $80 \%$ dan dari siklus II meningkat lagi pada siklus III menjadi 93,72\%. Berdasarkan uraian tersebut dapat diketahui bahwa persentase rata-rata dari siklus I ke siklus II, dan dari siklus II ke siklus III mengalami peningkatan. Hal tersebut dapat diperjelas pada grafik di bawah ini. 


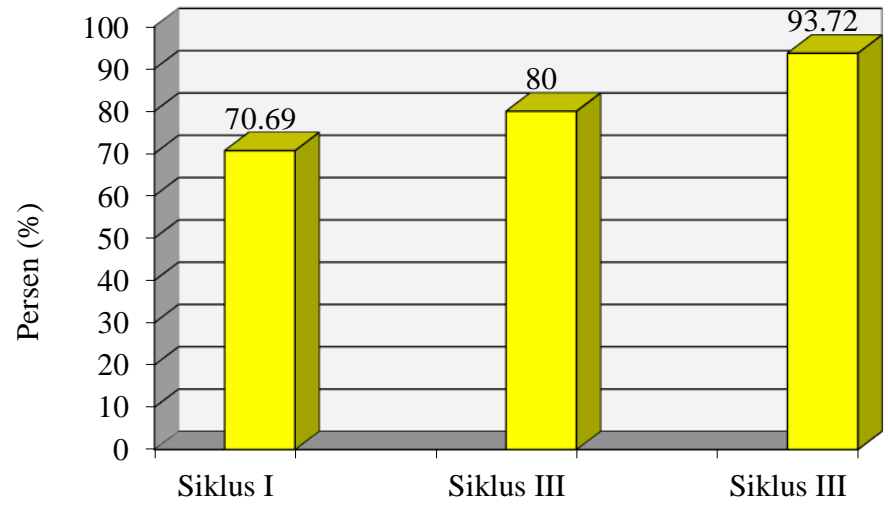

Grafik 1. Rekapitulasi peningkatan aktivitas siswa dalam proses pembelajaran

\section{Kesimpulan}

Berdasarkan hasil dan pembahasan yang telah di jelaskan, dapat disimpulkan bahwa: Pembelajaran menggunakan permainan bahasa dapat meningkatkan aktivitas siswa kelas IVA di SD Negeri 01 Metro Pusat. Berdasarkan hasil pembahasan setiap siklus diperoleh persentase rata-rata sebagai berikut.

a. Pada siklus I aktivitas siswa dalam pelaksanaan proses pembelajaran menggunakan permainan bahasa menunjukkan persentase rata-rata sebesar 70,69\%.

b. Pada siklus II aktivitas siswa dalam pelaksanaan proses pembelajaran menggunakan permainan bahasa menunjukkan peningkatan. Jika pada siklus I persentase rata-rata sebesar 70,69\% maka pada siklus II menjadi $80 \%$ meningkat sebesar 9,31\%, Namun belum mencapai indikator keberhasilan yang ditetapkan.

c. Pada siklus III aktivitas siswa dalam pelaksanaan proses pembelajaran menggunakan permainan bahasa menunjukkan peningkatan kembali. Jika pada siklus I persentase rata-rata sebesar $70,69 \%$, meningkat pada siklus II menjadi $80 \%$, maka pada siklus III menjadi 93,72\% meningkat sebesar $13,72 \%$, dan telah mencapai indikator keberhasilan yang ditetapkan.

Berdasarkan kesimpulan di atas, berikut ini disampaikan rekomondasi yang dapat diberikan.

a. Guru hendaknya dalam setiap pembelajaran selalu inovatif, kreatif, menarik, serta menyenangkan.

b. Dalam melaksanakan pembelajaran, sebaiknya guru benar-benar memegang prinsip-prinsip pelaksanaan serta terus mencoba, sampai bisa.

c. Pembelajaran menggunakan permainan bahasa ini menjadi salah satu rekomondasi bagus untuk dilaksanakan di tingkat sekolah dasar karena terbukti dapat meningkatkan aktivitas siswa.

\section{Daftar Pustaka}

Charner, Kathy, dkk. (2006). Brain Power Permainan Berbasis Sentra Pembelajaran. Jakarta: Erlangga Kids.

Djuanda, Dadan. (2006). Pembelajaran Bahasa Indonesia yang Komunikatif dan Menyenangkan. Jakarta: Departemen Pendidikan Nasional. 
Hamdani. (2011). Strategi Belajar Mengajar. Bandung: CV Pustaka Setia.

Mulyasa. (2002). Manajemen Berbasis Sekolah: Konsep, Strategi dan Implementasi. Bandung: Remaja Rosda Karya

Sudjana, N. (2004). Dasar-Dasar Proses Belajar Mengajar. Bandung: Sinar Baru Algessindo Suyatno. (2005). Permainan Pendukung Pembelajaran Bahasa dan Sastra. Jakarta: Grasindo.

Wardani, I.G.A.K. dkk. (2007). Penelitian Tindakan Kelas. Jakarta: Universitas Terbuka. 